\title{
Safety of warfarin therapy during cataract surgery under topical anesthesia
}

\section{Segurança da terapia com varfarina durante cirurgia de catarata com anestesia tópica}

\author{
Newton Kara-Junior ${ }^{1}$, Marcony R. Santhiago ${ }^{1}$, Hirlana Gomes Almeida ${ }^{1}$, Ana Carolina Raiza ${ }^{1}$
}

\begin{abstract}
Purpose: To analyze the safety of warfarin therapy during cataract surgery under topical anesthesia.

Methods: This was a prospective nonrandomized comparative study of 60 eyes of 60 patients treated with or without concurrent oral warfarin anticoagulant therapy, referred for cataract surgery under topical anesthesia. The sample included a treatment $(n=30)$ and a control $(n=30)$ group.

Results: There were no records of intraoperative or postoperative intracamera bleeding complications in both the groups. At 1-month postoperative follow-up $90.0 \%$ of patients presented spectacle-corrected visual acuity of at least 20/40 Conclusion: Cataract surgery by phacoemulsification with topical anesthesia can be successfully conducted without discontinuing warfarin.
\end{abstract}

Keywords: Cataract extraction; Anticoagulants; Warfarin/adverse effects; Hemorrhage

\section{RESUMO}

Objetivo: Avaliar a segurança da cirurgia de catarata com anestesia tópica em pacientes em uso de varfarina.

Métodos: Estudo comparativo não aleatorizado, prospectivo de 30 olhos de 30 indivíduos sob terapia anticoagulante por via oral com Varfarina que se submeteram à cirurgia de catarata com anestesia tópica. O grupo controle foi composto por 30 olhos de 30 pacientes, com indicação de cirurgia de catarata, que não faziam uso de terapia anticoagulante.

Resultados: Não houve registro de complicações hemorrágicas intracamerais transoperatórias ou pós-operatórias em ambos os grupos. Na visita pós-operatória de 30 dias, 90,0\% dos pacientes apresentavam acuidade visual corrigida por óculos de pelo menos 20/40.

Conclusão: A cirurgia de catarata por facoemulsificação com anestesia tópica pode ser realizada com sucesso sem interrupção da terapia com varfarina.

Descritores: Extração de catarata; Anticoagulantes; Varfarinalefeitos adversos; Hemorragia

\section{INTRODUCTION}

Most patients undergoing cataract surgery are elderly and are on regular systemic medications ${ }^{(1)}$. Important classes of drugs include antiplatelet and anticoagulant medications, which may increase the risk of hemorrhagic anesthetic, or operative complications. These medications are taken to reduce the incidence of potentially life-threatening thromboembolic events in patients with cardiovascular conditions ${ }^{(1)}$

The Royal College of Ophthalmologists Cataract Surgery Guidelines recommends that patients taking warfarin should continue it before cataract surgery but that the international normalized ratio (INR) should be maintained within the therapeutic level(2). Some studies have demonstrated that uncomplicated cataract surgery can be safely performed during oral anticoagulant therapy ${ }^{(3-5)}$.

This prospective study aimed to analyze the safety of warfarin therapy during cataract surgery under topical anesthesia.

\section{METHODS}

A prospective comparative study was conducted with 60 consecutive eyes of 60 patients treated at the Hospital das Clínicas da Faculdade de Medicina da Universidade de São Paulo for cataract surgery. The sample included 30 consecutive patients on oral anticoagulant therapy with warfarin and 30 controls who were not on anticoagulant therapy. The exclusion criterion was any ocular disease other than cataract.
The variables analyzed were international normalized ratio (INR) of the warfarin group, dosage of warfarin, postoperative visual acuity, and intraoperative and postoperative complications.

All patients underwent complete ophthalmic examination prior to cataract extraction by phacoemulsification with clear corneal incision and intraocular lens implantation, under topical anesthesia. No patient required intraoperative mechanical pupil dilation or corneal suture.

In the warfarin group, INR was determined 1 week prior to and on the day of surgery; INR between 1.9 and 2.7 was a prerequisite for undergoing cataract extraction according to our surgical protocol.

Data were analyzed by descriptive statistical methods, and categorical variables are expressed as absolute frequencies.

\section{RESULTS}

Among the 30 patients undergoing anticoagulant therapy with warfarin, 23 were taking a 5.0-mg dose per day and seven were taking $2.5 \mathrm{mg}$ per day. The mean INR value was 2.04 .

No intracameral perioperative bleeding or postoperative hemorrhagic complications were observed in the treatment or control group. With regard to the postoperative visual outcome, $90 \%$ of the patients had a visual acuity of 20/40 or better at 1-month follow-up.

\section{DISCUSSION}

Prophylactic anticoagulation has been of paramount importance in preventing coronary ischemic events, stroke, and peripheral arte-
Submitted for publication: November 7, 2014

Accepted for publication: April 5, 2015

Department of Ophthalmology, Faculdade de Medicina, Universidade de São Paulo (USP), São Paulo, SP, Brazil.
Funding: No specific financial support was available for this study.

Disclosure of potential conflicts of interest: None of the authors have any potential conflict of interest to disclose.

Corresponding author: Hirlana Gomes Almeida. R. Carlos Sampaio, 210/113 - São Paulo, SP 01333-020 - Brazil - E-mail: hirlanaa@hotmail.com 
rial obstruction. However, it is well known that patients on anticoagulation therapy are exposed to a greater risk of hemorrhage when undergoing surgical treatment ${ }^{(6)}$.

This increased risk makes these patients represent a challenge to cataract surgeons. Continuing antiplatelet and anticoagulation therapies may place these patients at risk of bleeding complications, whereas discontinuing these medications puts them at risk of thromboembolic complications ${ }^{(7-9)}$.

Annually, $10 \%$ of patients receiving oral anticoagulants require treatment interruption for surgery or an invasive procedure ${ }^{(4)}$. A multicenter audit has shown that $5.1 \%$ of 48,862 patients subjected to cataract surgery were on concurrent warfarin therapy ${ }^{(1)}$. Considering the long and variable half-life of vitamin K antagonists, some guidelines recommend that patients should discontinue warfarin at least 5 days before major procedures ${ }^{(10-12)}$.

The incidences of subconjunctival hemorrhage and microscopic hyphema were significantly higher in patients undergoing phacoemulsification without warfarin interruption compared with the discontinuation subgroup, although most of such bleeds were self-limiting and did not significantly decrease visual acuity ${ }^{(13-15)}$. Most members of the Canadian Society of Cataract and Refractive Surgery do not recommend suspending warfarin prior to cataract surgery ${ }^{(16)}$. However, it has been presented that most glaucoma surgeons discontinue the use of anticoagulants (warfarin or aspirin) before antiglaucoma surgery ${ }^{(17)}$.

The results of the present study are in agreement with reports in the literature that state that there is no significant increase in bleeding that could potentially afflict vision in patients undergoing cataract surgery while using antiplatelet or anticoagulant therapy ${ }^{(1,18,19)}$, particularly when the surgery is conducted under topical anesthesia ${ }^{(20,21)}$. Thus, in this series, phacoemulsification cataract surgery under topical anesthesia was safely performed without discontinuing warfarin anticoagulation in uncomplicated eyes. However, larger studies are required to elucidate this issue.

\section{REFERENCES}

1. Benzimra JD, Johnston RL, Jaycock P, Galloway PH, Lambert G, Chung AKK et al. The Cataract National Dataset electronic multicentre audit of 55,567 operations: antiplatelet and anticoagulant medications. Eye (Lond). 2009;23(1):10-6.

2. The Royal College of Ophthalmologists. Cataract surgery guidelines. 2004. [Internet].
Available from: http://rcophth-website.www.premierithosting.com/docs/publications/published-guidelines/FinalVersionGuidelinesApril2007Updated.pdf

3. Barequet IS, Sachs D, Priel A, Wasserzug Y, Martinowitz U, Moisseiev J et al. Phacoemulsification of Cataract in Patients Receiving Coumadin Therapy: Ocular and Hematologic Risk Assessment. Am J Ophthalmol. 2007:144(5):719-23.

4. Ong-Tone L, Paluck EC, Hart-Mitchell RD. Perioperative use of warfarin and aspirin in cataract surgery by Canadian Society of Cataract and Refractive Surgery members: survey. J Cataract Refract Surg. 2005;31(5):991-6.

5. Rotenstreich Y, Rubowitz A, Segev F, Jaeger-Roshu S, Assia El. Effect of warfarin therapy on bleeding during cataract surgery. J Cataract Refract Surg. 2001:27(9):1344-46.

6. Dunn AS, Turpie AG. Perioperative management of patients receiving oral anticoagulants: a systematic review. Arch Intern Med. 2003;163(8):901-8.

7. Jafri SM. Periprocedural thromboprophylaxis in patients receiving chronic anticoagulation therapy. Am Heart J. 2004;147(1):3-15.

8. Douketis JD, Berger PB, Dunn AS, Jaffer AK, Spyropoulos AC, Becker RC, Ansell J; American College of Chest Physicians. The perioperative management of antithrombotic therapy: American College of Chest Physicians Evidence-Based Clinical Practice Guidelines (8th Edition). Chest. 2008;133(6):299-339.

9. Wahl MJ. Dental surgery in anticoagulated patients. Arch Intern Med. 1998 Aug 10-24; 158(15):1610-6. Review.

10. Katz J, Feldman MA, Bass EB, Lubomski LH, Tielsch JM, Petty BG, Fleisher LA, Schein OD; Study of Medical Testing for Cataract Surgery Team. Risks and benefits of anticoagulant and antiplatelet medication use before cataract surgery. Ophthalmology. 2003; 110(9):1784-8. Erratum in: Ophthalmology. 2003:110(12):2309.

11. Alwitry A, King AJ, Vernon SA. Anticoagulation therapy in glaucoma surgery. Graefes Arch Clin Exp Ophthalmol. 2008;246(6):891-6.

12. Oh J, Smiddy WE, Kim SS. Antiplatelet and anticoagulation therapy in vitreoretinal surgery. Am J Ophthalmol. 2011;151(6):934-9.

13. Jamula E, Anderson J, Douketis JD. Safety of continuing warfarin therapy during cataract surgery: a systematic review and meta-analysis. Thromb Res. 2009;124(3):292-9.

14. Morris A, Elder MJ. Warfarin therapy and cataract surgery. Clin Experiment Ophthalmol. 2000;28(6):419-22.

15. Kobayashi H. Anticoagulant and antiplatelet use in cataract surgery and combined with posterior vitrectomy [Internet]. [cited 2015 Apr 11]. Available from: http://cdn. intechopen.com/pdfs-wm/42725.pdf.

16. Leaming DV. Practice styles and preferences of ASCRS members-2003 survey. J Cataract Refract Surg. 2004;30(4):892-900

17. Balbino M, Boin P, Prata TS. Perioperative management of anticoagulant users scheduled for glaucoma surgery: a survey among the Brazilian Glaucoma Society members. Arq Bras Oftalmol. 2013;76(6):363-5.

18. McMahan LB. Anticoagulants and cataract surgery. J Cataract Refract Surg. 1988;14(5): 569-71.

19. Gainey SP, Robertson DM, Fay W, Ilstrup D. Ocular surgery on patients receiving long-term warfarin therapy. Am J Ophthalmol. 1989;108(2):142-6.

20. Robinson GA, Nylander A. Warfarin and cataract extraction. Br J Ophthalmol. 1989; 73(9):702-3.

21. Konstantatos A. Anticoagulation and cataract surgery: a review of the current literature. Anaesth Intensive Care. 2001;29(1):11-8. 